\title{
Nucleic Acid Cleavage
}

National Cancer Institute

\section{Source}

National Cancer Institute. Nucleic Acid Cleavage. NCI Thesaurus. Code C41591.

Nucleic Acid Cleavage is any process that hydrolytically cleaves either the glycosidic bond or the sug ar-phospate ester bond of a olig oribonucleotide or deoxyolig oribonucleotide polymer. This process can occur with or without the involvement of an enzyme. This term does not apply to the disruption of hydrogen bonds that stabilize DNA and RNA molecules. 